\title{
Purification and Characterization of a $\beta$-Glucanase Produced by Trichoderma harzianum Showing Biocontrol Potential
}

\author{
Janice Lisboa de Marco and Carlos Roberto Felix ${ }^{*}$ \\ Departamento de Biologia Celular; Universidade de Brasília; carlosrf@unb.br; 70910-900; Brasília - DF - Brasil
}

\begin{abstract}
A $\beta$-1,3-glucanase was produced by Trichoderma harzianum in cultures containing chitin as the sole substrate. Two proteins showing $\beta$-1,3-glucanase activity were purified to apparent homogeneity by hydrophobic chromatography. The molecular masses of these proteins were 29 and $36 \mathrm{kDa}$. The $36 \mathrm{kDa}$ protein was further characterized. It was active on a broad $\mathrm{pH}$ range, and maximal activity was detected at pH 5.0. The optimum temperature of the $36 \mathrm{kDa}$ $\beta$-1,3-glucanase was $50^{\circ} \mathrm{C}$, but the purified enzyme was very sensitive to temperature. It lost about $60 \%$ or more of the activity after incubation for $30 \mathrm{~min}$ at 45, 50 and $60^{\circ} \mathrm{C}$. The apparent $K_{M}$ and $V_{\text {max }}$ for hydrolysis of laminarin at pH 5.0 and $37^{\circ} \mathrm{C}$, were $0.099 \mathrm{mg}$ of reducing sugar $/ \mathrm{mL}$ and $0.3 \mathrm{mg}$ of reducing sugar/min.mL, respectively. The enzyme was insensitive to organic compound and metal ions, except for the ferric ion which inhibited about $100 \%$ of the original activity at the concentration of $1 \mathrm{mM}$. In contrast to other hydrolytic enzymes ( $a$ chitinase and a protease) produced by the same T. harzianum isolate (1051), the $\beta$-1,3-glucanase showed no effect on the cell wall of the phytopathogenic fungus Crinipellis perniciosa.
\end{abstract}

Key words: Trichoderma harzianum , $\beta$-1,3-glucanase, chitinase, proteases

\section{INTRODUCTION}

A linear 1,3-1,4- $\beta$-glucan which accounts for up to $5.5 \%$ of the dry weight of grains is the major cell wall polysaccharide in the endosperm of cereals (McCleary, 1988) The bulk of the polysaccharide consists of short regions of $\beta-1,4-$ linked glucose residues (three to four) interrupted by a single $\beta$ 1,3-linkage (Dais and Perlin, 1982). Cereals have a high water-binding capacity and form highly viscous solutions and gelatinous suspensions in aqueous media. Consequently, the brewing industries faces problems such as increased worth viscosity, longer process times for beer filtration and $\beta$-glucan precipitation in beer (Bamforth and
Quain, 1990) In addition, excess cell wall $\beta$-glucan impairs malt extraction, leading to prolonged malting times and a decrease in the brewhouse yield (Esslinge et al., 1985). The presence of cereal $\beta$-glucan in poultry and animal diet is similarly problematic in that "gummy" and indigestible $\beta$-glucans have inconsistent nutritional values, contribute to wet and sticky faeces and depress animal performance (Jeroch et al., 1988). Therefore, enzymes that catalyze depolymerization of selective modification of cereal $\beta$-glucans are of biotechnological and biomedical importance (McCleary et al., 1988). $\beta$-glucan-degrading enzymes are produced by a wide variety of organisms. Several types of these enzymes exist,

\footnotetext{
${ }^{*}$ Author for correspondence
} 
classified according to the type of $\beta$-glucosidic linkage that they cleave and the mechanism of substrate attack. They can hydrolyze the substrate by two possible mechanisms, identified by the products of hydrolysis: (i) exo- $\beta$-glucanase hydrolyze the substrate by sequentially cleaving glucose residues from the nonreducing end, or (ii) endo- $\beta$-glucanases cleave $\beta$-linkage at random sites along the polysaccharide chain, releasing smaller oligosaccharides. Degradation of $\beta$-glucan by fungi is often accomplished by the synergistic action of both endo- and exo- $\beta$-glucanases (Pitson et al., 1993).

On the other hand, the cell walls of the plant pathogens Sclerotium rolfsii, Rhizoctonia solani, and Pythium sp (Chet, 1987) are largelly composed of $1,3-\beta$-glucans and chitin, with cellulose also found in Oomycetes, e.g., Pythium spp. (Bartinicki-Garcia, 1973). In recent years several works have suggested that chitinase and $\beta$ glucanase producing fungi, i.e., species of Trichoderma, could be effective as biological control agents. Micoparasitism has been described as the main process involved in the antagonistic action of Trichoderma harzianum against fungal pathogens. It is a complex process that includes the release of lytic enzymes by the Trichoderma, degradation of the cell wall (Lima et al., 1997), and further penetration in the host mycelium (Chérif and Benhamou, 1990). Two Trichoderma isolates (1051 and TVC), previously found to control witches' broom of cocoa under field conditions (José Luiz Bezerra, personal communication), produced substantial amounts of chitinase, $\quad \mathrm{N}$-acetylglucosaminidases, $\quad \beta$ glucanases, proteases, cellulases and amylases in cultures containing the corresponding substrates (De Marco et al., 2003). Studies have been reported on the purification and characterization of one chitinase (De Marco et al., 2000), one protease (De Marco and Felix, 2002), one amylase (Azevedo et al., 2000), and one Nacetylglucosaminidase (De Marco et al., 2004) produced by the isolate 1051 . While the chitinase strongly attacked the Crinipellis perniciosa cell wall, the protease and the Nacetylglucosaminidase were less effective, and the amylase had no effect at all. Here, we report on the purification and characterization of a $\beta$-glucanase produced by $T$. harzianum 1051 growing in liquid medium containing chitin as the sole carbon source, and on the lack of action of this enzyme on the $C$. perniciosa cell wall.

\section{MATERIALS AND METHODS}

\section{Strain origin and maintenance}

Trichoderma harzianum, isolate 1051, was obtained from the collection of the Centro Nacional de Pesquisa de Monitoramento e Avaliação de Impacto Ambiental (CNPMA/EMBRAPA, Jaguariuna, SP, Brazil -the National Research Center for Monitoring and Environmental Impact Assessment). The phytopathogen $C$. perniciosa was kindly provided by Dr. José Luiz Bezerra from CEPLAC/Ilheus, BA, Brazil. Both microorganisms were maintained by serial passages on potato-dextrose agar medium (Difco).

\section{Enzyme production and assay}

For enzyme production, T. harzianum spores $(2 \mathrm{x}$ $10^{6}$ ) were inoculated in $250 \mathrm{~mL}$ TLE liquid medium $(0.1 \%$ bactopeptone; $0.03 \%$ urea; $0.2 \%$ $\mathrm{KH}_{2} \mathrm{PO}_{4} ; 0.14 \%\left(\mathrm{NH}_{4}\right)_{2} \mathrm{SO}_{4} ; 0.03 \% \mathrm{MgSO}_{4} \cdot 7 \mathrm{H}_{2} \mathrm{O}$; $0.03 \% \mathrm{CaCl}_{2} \cdot 6 \mathrm{H}_{2} \mathrm{O} ; 1 \mathrm{~mL}$ of $0.01 \%$ trace elements solution $\left(\mathrm{Fe}^{2+}, \mathrm{Mn}^{2+}, \mathrm{Zn}^{2+}\right.$, and $\left.\mathrm{Co}^{2+}\right), 0.02 \%$ glucose, $\mathrm{pH} 5.5)$ containing chitin $(0.5 \%)$, for $72 \mathrm{~h}$ at $28^{\circ} \mathrm{C}$. The cultures were incubated for $0-72 \mathrm{~h}$ at $28^{\circ} \mathrm{C}$, with agitation $(250 \mathrm{rpm})$. The culture supernatants were separated from the mycelium by filtration through filter paper, and used for enzyme assay and/or enzyme purification as described in the section below.

$\beta$-glucanase activity was assayed (in triplicate) using a reaction system containing $250 \mu \mathrm{L}$ of a laminarin solution (1\%) dissolved in $50 \mathrm{mM}$ sodium acetate buffer, pH.5.0 and $0-125 \mu \mathrm{L}$ of enzyme solution. Reaction was allowed to proceed for $30 \mathrm{~min}$ at $37^{\circ} \mathrm{C}$ and stopped by addition of 1.5 $\mathrm{mL}$ of 3,5-dinitrosalicylic acid reagent. The reducing sugar formed was then determined spectrophotometrically at $550 \mathrm{~nm}$ according to Miller (1959). One unit of enzyme (U) was defined as the amount of protein necessary to produce one micromole of reducing sugar per min. For determination of optimum $\mathrm{pH}$, the assays were run for $30 \mathrm{~min}$ at $37^{\circ} \mathrm{C}$, using the buffer solutions $(50 \mathrm{mM})$ of sodium acetate $(\mathrm{pH} 3.0-5.0)$, sodium phosphate $(\mathrm{pH} 6.0$ - 8.0) and Tris- $\mathrm{HCl}(\mathrm{pH} 9.0)$ containing the substrate laminarin. In all cases, the standard deviation values for enzyme activity were 
smaller than $5 \%$ of the mean values. For determination of $\mathrm{K}_{\mathrm{M}}$ and $\mathrm{V}_{\max }$ of laminarin hydrolysis, the concentrations of this substrate varied from $0.1 \mathrm{mg}$ to $20.0 \mathrm{mg} / \mathrm{mL}$.

\section{Enzyme purification}

To the supernatants from $T$. harzianum 1051 cultures obtained as described above, $\left(\mathrm{NH}_{4}\right)_{2} \mathrm{SO}_{4}$ was added to a concentration of $40 \%$. The mixtures were kept for $15 \mathrm{~min}$ at $4^{\circ} \mathrm{C}$ under gentle agitation. Suspensions were centrifuged at 28,800 $\mathrm{g}$ for $30 \mathrm{~min}$, and the pellets were discarded. Ammonium sulfate was then added to supernatants for a final concentration of $60 \%$. After $15 \mathrm{~min}$ at $4^{\circ} \mathrm{C}$ under gentle agitation, the supernatants were centrifuged as above, and the resulting pellets resuspended in a small volume of $50 \mathrm{mM}$ sodium acetate $\mathrm{pH}$ 5.0, and used as crude enzyme preparation. Samples of crude enzyme were then loaded on a Phenyl Sepharose CL 4B column (10 x $1.8 \mathrm{~cm}$ ) equilibrated with acetate buffer $50 \mathrm{mM}$, $\mathrm{pH}$ 5.0. Proteins were then eluted with a negative gradient formed with $40 \mathrm{~mL}$ of the acetate buffer containing $1 \mathrm{M}$ ammonium sulfate, and $40 \mathrm{~mL}$ of the acetate buffer. Samples of $2.6 \mathrm{~mL}$ were collected at a flow rate of $52 \mathrm{~mL} / \mathrm{h}$. Protein $\left(\mathrm{A}_{280 \mathrm{~nm}}\right)$ and $\beta$-glucanase activity were monitored for each sample. Fractions containing the enzyme were pooled, dialyzed against distilled water, and concentrated by freeze-drying.

The concentration of protein in the enzyme samples was determined by a simplification of the method of Lowry et al. (Peterson, 1977).

\section{SDS-PAGE analysis}

$\beta$-glucanase samples were analysed by electrophoresis in polyacrylamide gels under denaturing conditions, according to Laemmli (1970). Proteins present in the gels were stained with silver reagent according to the method of Blum et al. (1987).

\section{Enzymatic digestion of Crinipellis perniciosa mycelium and scanning electron microscopy (SEM) analysis}

Disks $(5 \mathrm{~mm})$ of solid culture medium containing $C$. perniciosa mycelium were placed in microcentrifuge tubes containing $1 \mathrm{~mL}$ of either $T$. harzianum 1051 culture supernatant showing $\beta$ glucanase activity $(2.2 \mathrm{U} / \mathrm{mL})$, or the corresponding purified enzyme $(0.47 \mathrm{U} / \mathrm{mL})$. After incubation for $96 \mathrm{~h}$ at $37^{\circ} \mathrm{C}$, the supernatants were used for determination of reducing sugars by the dinitrosalicylic acid method (DNS assay) according to Miller (1959), glucose by the glucose oxidase method (glucose-oxidase assay, Doles Reagents kit, Goiania, GO, Brazil) and protein by a simplification of the method of Lowry et al.. (Peterson, 1977). The C. perniciosa mycelium disks, treated or without $\beta$-glucanase, were then fixed for $2 \mathrm{~h}$ at $4^{\circ} \mathrm{C}$ in $2 \%(\mathrm{v} / \mathrm{v})$ glutaraldehyde and $2 \%(\mathrm{w} / \mathrm{v})$ paraformaldehyde, buffered with $0.05 \%$ sodium cacodylate buffer, $\mathrm{pH}$ 7.2, and postfixed in $1 \%(\mathrm{w} / \mathrm{v})$ osmium tetroxide in the same buffer. The specimens were washed with buffer and dehydrated in 30-100\% (v/v) acetone, criticalpoint dried in $\mathrm{CO}_{2}$ and sputter-coated with gold. Materials were examined microscopically at an accelerating voltage of $10.0 \mathrm{kV}$. Disks of solid medium containing $C$. perniciosa treated with heat denatured $\beta$-glucanase were used as a control.

\section{RESULTS AND DISCUSSION}

\section{Production of $\beta$-1,3-glucanase}

The production of extracellular $\beta$-glucanase was monitored during growth of $T$. harzianum isolate 1051 growing in TLE liquid medium supplemented with $0.5 \%$ chitin. As shown in Fig. 1, the enzyme activity present in the culture supernatant increased rapidly after $24 \mathrm{~h}$, and a higher enzyme level was detected with $72 \mathrm{~h}$ of growth. This enzyme was considered to be a $\beta$ 1,3-glucanase, or laminarinase (1,3-glucan-3glucanohydrolase; EC 3.2.1.39), since it hydrolysed laminarin, a poly $\beta(1 \rightarrow 3)$-glucan, a substrate for laminarinase. $\beta$-glucanases are produced and secreted into the culture medium by a wide variety of fungi in response to the presence of chitin (Noronha and Ulhoa, 2000; Pitson et al., 1993). Frequently, in nature, Trichoderma $\beta-1,3-$ glucanases are responsible for hydrolysis of phytopathogenic fungi during a mycoparasite attack (Herrera-Estrella and Chet, 1998). In fact, $\beta$-1,3-glucanase activity was also found in cultures containing purified cell walls from Rhizoctonia solani, Sclerotium rolfsii and Pythium spp. as inducer (Noronha and Ulhoa, 2000). In this case, the enzyme activity was higher in the culture containing Pythium spp. cell wall, suggesting that secretion of $\beta-1,3$-glucanases was greatly influenced by the levels of $\beta$-glucan present in the cell walls of this phytopathogenic fungus. The 
possible action of the $\beta-1,3$-glucanase produced by the Trichoderma isolate 1051, on cereal $\beta$-glucans, which caused problems in brewing industry and which affected the performance of poultry and animal diets (Murray et al., 2001) could be an opening for additional investigation.

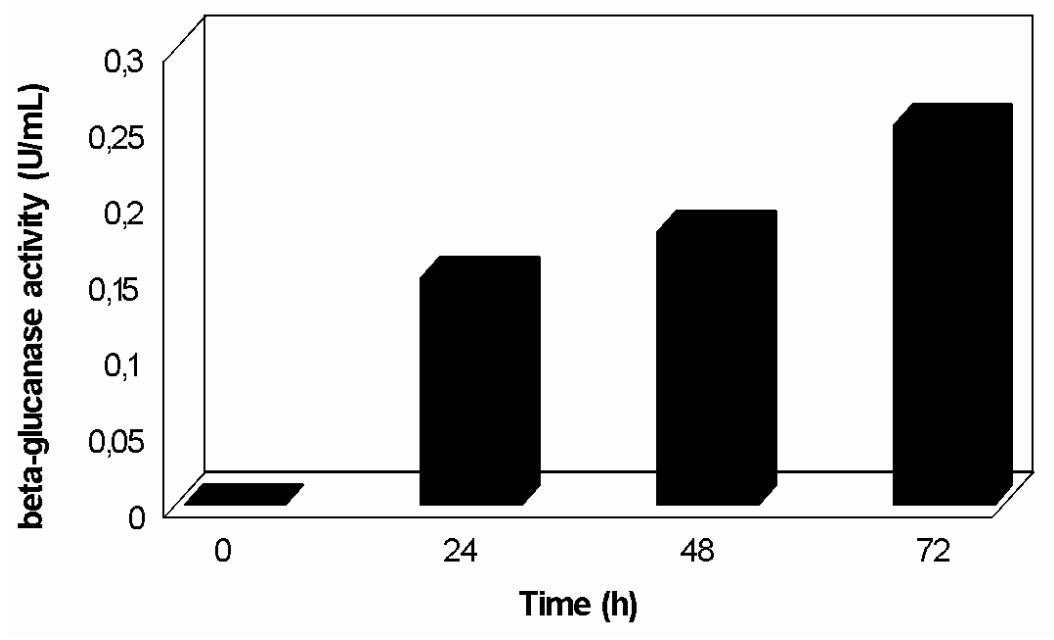

Figure 1 - Time course of $\beta$-1,3-glucanases produced by T. harzianum 1051 in liquid medium containing chitin $(0.5 \%)$, under agitation $(130 \mathrm{rpm})$ at $28^{\circ} \mathrm{C}$.

\section{Purification of the $\beta-1,3$-glucanase}

The proteins showing $\beta$-1,3-glucanase activity were separated by fractionated precipitation with ammonium sulfate. In the presence of $40 \%$ of ammonium sulfate, very low, or no $\beta-1,3-$ glucanase was precipitated. However, the bulk of the enzyme present in solution was removed with $60 \%$ of the ammonium salt. The protein present in the resulting pellet was easily fractionated by hydrophobic chromatography in a Phenyl Sepharose CL 4B column. Relevant $\beta-1,3-$ glucanase activity was eluted in two major overlapping peaks (Fig. 2). SDS-polyacrilamide gel electrophoresis revealed that peak number one contained a single protein having $\beta$-1,3-glucanase activity and a molecular mass of $29 \mathrm{kDa}$; and the second peak, a $\beta$-1,3-glucanase of molecular mass of $36 \mathrm{kDa}$ (Fig. 3). It was previously reported that $T$. harzianum produced three $\beta-1,3$-glucanases in the presence of chitin as carbon source. One of these enzymes was purified and characterized as an endo- $\beta$-1,3-glucanase with a molecular mass of $36 \mathrm{kDa}$ (Noronha and Ulhoa, 1996). Another $\beta$ 1,3-glucanase produced by T. harzianum (Tc) also showed a molecular mass of $36 \mathrm{kDa}$ (Noronha and Ulhoa, 2000). Although different approaches were used to purify these enzymes, it was likely that the two $\beta$-1,3-glucanases (29 $\mathrm{kDa}$ and $36 \mathrm{kDa})$ reported here and those reported by were Noronha and Ulhoa $(1996 ; 2000)$ are the same protein. While low molecular weight $\beta-1,3$-glucanases were also present in phytopathogenic fungi like Rhizoctonia solani (Totsuka and Usui, 1986), a high molecular mass extracellular endo- $\beta-1,3-$ glucanase was produced by the mycoparasitic fungus T. harzianum (CECT 2413). The gene encoding this enzyme was cloned and found to encode a protein of a molecular mass of $78 \mathrm{kDa}$ (De La Cruz et al., 1995).

\section{Optimal pH and temperature, and stability of the $36 \mathrm{kDa} \beta$-1,3-glucanase}

The purified $36 \mathrm{kDa} \beta-1,3$-glucanase displayed activity over a broad $\mathrm{pH}$ range, i.e., activity was detected at $\mathrm{pH}$ from 3-9 at the temperature of $37^{\circ} \mathrm{C}$. However, maximal activity was measured at $\mathrm{pH}$ 5.0, and decreasing activity was detected when the enzyme assays were performed in conditions having lower, or higher $\mathrm{pH}$ values (Fig. 4A). 


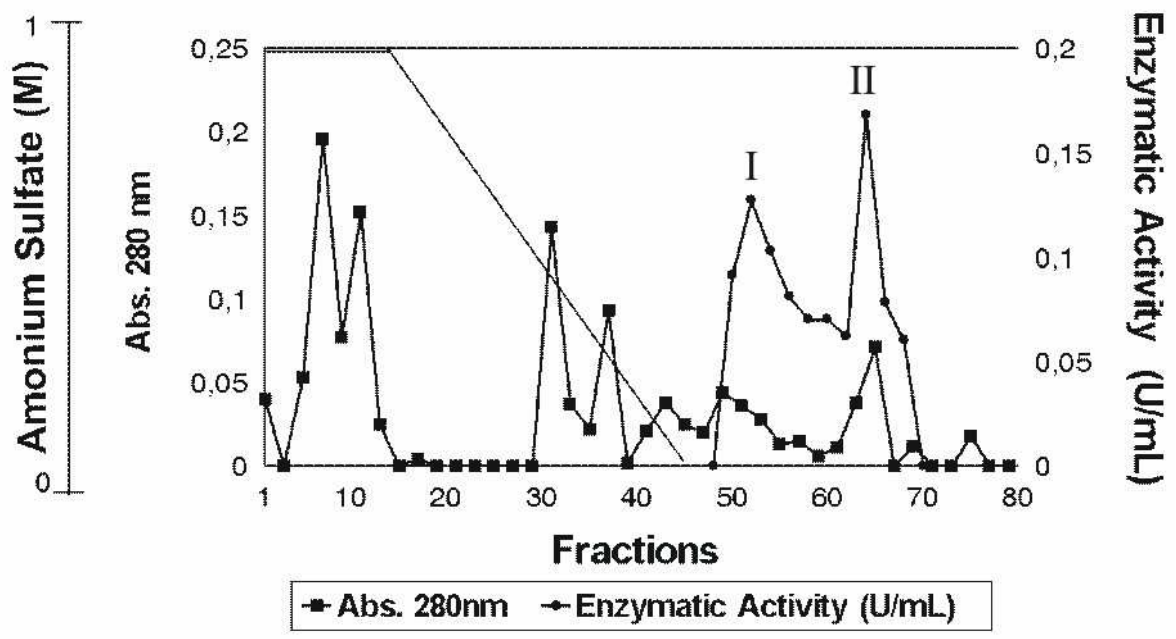

Figure 2 - Phenyl Sepharose CL 4B hydrophobic chromatography (10 x $1.8 \mathrm{~cm}$ column) of the culture filtrate of $T$. harzianum 1051 grown in the presence of chitin (see fig. 1). The culture supernatant was submitted to precipitation with ammonium sulfate as described in material and methods. The diagonal line indicates the ammonium sulfate gradient formed with 0 to $1 \mathrm{M}$.

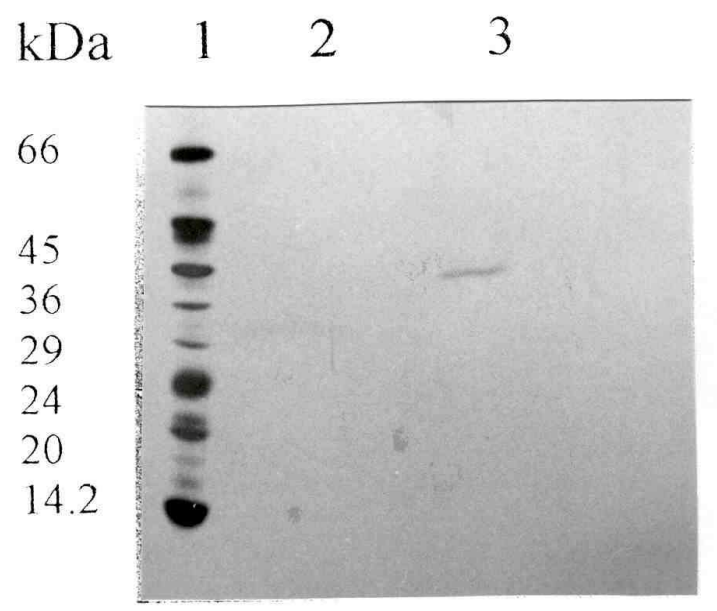

Figure 3 - SDS-PAGE of the $\beta$-1,3-glucanase from $T$. harzianum 1051 purified on a PhenylSepharose column. 1, molecular weight standards; 2, 29 kDa $\beta$-1,3-glucanase purified; 3, $36 \mathrm{kDa}$ purified $\beta$-1,3-glucanase.

Substantial enzyme activity could be measured into a temperature range of $20-80^{\circ} \mathrm{C}$. The optimum temperature for this enzyme was $50^{\circ} \mathrm{C}$ (Fig.4B). The optimal $\mathrm{pH}$ and temperature values found for $36 \mathrm{kDa} \beta$-1,3-glucanase was very close or the same as those calculated for the $29 \mathrm{kDa}(\mathrm{pH} \mathrm{4.4}$, and temp. $\left.50^{\circ} \mathrm{C}\right)$ and the $36 \mathrm{kDa}(\mathrm{pH} 4.4$, and temp. $\left.45-50^{\circ} \mathrm{C}\right) \quad \beta-1,3$-glucanases reported by
Noronha and Ulhoa (1996; 2000). However, 36 $\mathrm{kDa}$ purified $\beta$-1,3-glucanase was not resistant to temperature. At temperatures varying from $45^{\circ} \mathrm{C}$ to $60^{\circ} \mathrm{C}$, the $36 \mathrm{kDa}$ enzyme lost almost all its activity within $30 \mathrm{~min}$ (Fig. 4C). 

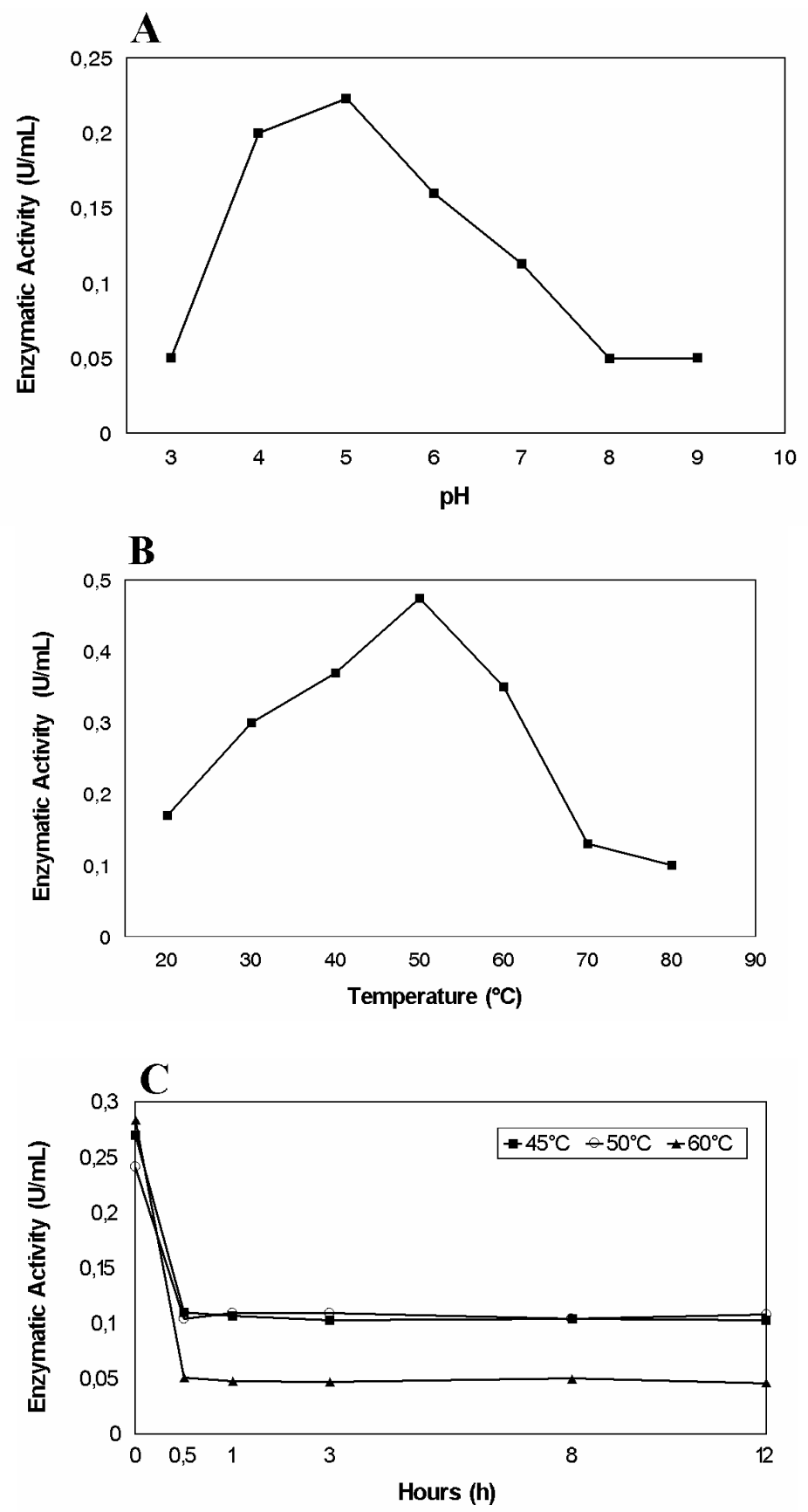

Figure 4 - $\mathrm{pH}$ (A) [the effect of $\mathrm{pH}$ was determined by varying the $\mathrm{pH}$ of the reaction mixtures by using 50mM sodium acetate $(\mathrm{pH} 3.0-5.0), 50 \mathrm{mM}$ sodium fosfate $(\mathrm{pH} 6.0-8.0), 50 \mathrm{mM}$ Tris $\mathrm{HCl}$ ( $\mathrm{pH} 9.0)]$, temperature $(\mathbf{B})$, and thermostability $(\mathbf{C})$ profiles of the purified 36 kDa $\beta$-1,3-glucanase from T. harzianum 1051.

This low thermostability was in agreement with the data found by Noronha and Ulhoa for the 29 $\mathrm{kDa} \beta$-1,3-glucanase (Noronha and Ulhoa, 2000) but not for the $36 \mathrm{kDa} \beta$-1,3-glucanase (Noronha and Ulhoa, 1996), which was found to be fairly resistant to temperature. Nevertheless, these values reported above were much lower than the optimal temperatures reported for $\beta$-glucanase produced by extremophilic microorganisms. A lichenase from the anaerobic thermophilic bacterium Clostridium thermocellum was reported to have an optimum temperature of $80^{\circ} \mathrm{C}$ 
(Schwimming et al., 1991). A purified endoglucanase active on 1,3-1,4- $\beta$-D-glucans produced by the moderately thermophilic aerobic fungus Talaromyces emersonii CBS 814.70 displayed activity over a broad range of $\mathrm{pH}$ and temperature, yielding optimal values of $\mathrm{pH} 4.8$ and $80^{\circ} \mathrm{C}$. This enzyme was markedly thermostable with $15 \%$ of its original activity remaining after incubation for $15 \mathrm{~min}$ at $100^{\circ} \mathrm{C}$ (Murray et al., 2001). Although the enzyme was composed of a single protein with a molecular mass of $40.7 \mathrm{kDa}$, its carbohydrate content was estimated to be $77 \%$ $(\mathrm{w} / \mathrm{w})$. The $35.9 \mathrm{kDa}$ endo-1,4- $\beta$-glucanase from the thermophilic bacterium Pyrococcus furiosus had a temperature optimum of $100^{\circ} \mathrm{C}$, and the $\mathrm{t}_{1 / 2}$ at $95^{\circ} \mathrm{C}$ was $40 \mathrm{~h}$. The denaturing temperature reported for this enzyme was $112^{\circ} \mathrm{C}$ (Bauer et al., 1999).

\section{Kinetics of substrate hydrolysis and the effect of ion on the $36 \mathrm{kDa} \beta$-1,3-glucanase}

The effect of laminarin on the activity of the purified $36 \mathrm{kDa} \quad \beta$-1,3-glucanase from $T$. harzianum 1051 was analyzed. At $37^{\circ} \mathrm{C}$ and $\mathrm{pH}$
5.0, the enzyme hydrolyzed laminarin with a Michaelis-Menten kinetic (not shown). The $\mathrm{K}_{\mathrm{M}}$ $(0.099 \mathrm{mg} / \mathrm{mL})$ and $\mathrm{V}_{\max }(0.3 \mathrm{mg} / \mathrm{min} \cdot \mathrm{mL})$ values for laminarin hydrolysis were determined using a non-linear regression data analysis program (Curve expert program 1.24 for Windows). This $\mathrm{K}_{\mathrm{M}}$ value was lower than those previously reported for laminarin hydrolysis by the previously reported $36 \mathrm{kDa} \beta$-1,3-glucanase $(1.18 \mathrm{mg} / \mathrm{mL})$ (Noronha and Ulhoa, 1996), the $29 \mathrm{kDa} \beta-1,3$-glucanase $(1.72 \mathrm{mg} / \mathrm{mL})$ (Noronha and Ulhoa, 2000) and the $70 \mathrm{kDa} \beta$-1,3-glucanase (3.3 mg/mL) (De La Cruz et al., 1995) produced by $T$. harzianum.

The effects of metal ions and organic compounds on the activity of the $36 \mathrm{kDa} \beta$-1,3-glucanase from T. harzianum are shown in Table 1. Except for the $\mathrm{FeCl}_{3}$, which showed a markedly inhibitory effect (98.6\%), all the ions tested were ineffective and/or showed a very low effect. The detergent SDS and the reducing agent $\beta$-mercaptoethanol did not drastically affect the enzyme.

Table 1 - The effect of ions on the activity of the purified $\beta$-1,3-glucanase from T. harzianum 1051.

\begin{tabular}{|c|c|c|}
\hline Reagents & Enzymatic activity (U/mL) & Relative activity (\%) \\
\hline Control & $4.89 \pm 0.009$ & 100 \\
\hline SDS (1mM) & $4.38 \pm 0.02$ & 89.4 \\
\hline$\beta$-mercapt. (1mM) & $4.6 \pm 0.019$ & 94 \\
\hline $\mathrm{FeCl}_{3}(1 \mathrm{mM})$ & $0.072 \pm 0$ & 1.4 \\
\hline $\mathrm{MgSO}_{4}(1 \mathrm{mM})$ & $4.07 \pm 0.0028$ & 83 \\
\hline $\mathrm{MgSO}_{4}(5 \mathrm{mM})$ & $4.19 \pm 0.043$ & 86 \\
\hline $\mathrm{AlCl}_{3}(1 \mathrm{mM})$ & $4.56 \pm 0.004$ & 93 \\
\hline $\mathrm{AlCl}_{3}(5 \mathrm{mM})$ & $5.66 \pm 0.007$ & 115 \\
\hline $\mathrm{ZnSO}_{4}(1 \mathrm{mM})$ & $4.45 \pm 0.002$ & 91 \\
\hline $\mathrm{ZnSO}_{4}(5 \mathrm{mM})$ & $4.5 \pm 0.005$ & 92 \\
\hline $\mathrm{CaCl}_{2}(1 \mathrm{mM})$ & $4.75 \pm 0.018$ & 97 \\
\hline $\mathrm{CaCl}_{2}(5 \mathrm{mM})$ & $5.3 \pm 0.011$ & 108 \\
\hline
\end{tabular}

Action of the $36 \mathrm{kDa} \beta-1,3$-glucanase on the Crinipellis perniciosa cell wall

Incubation of the mycelium of $C$. perniciosa with the crude extract containing $\beta$-1,3-glucanase activity did not result in the production of reducing sugars, or glucose (data not shown). According to the electron microscopy analysis of the $C$. perniciosa mycelium treated or without the crude, or the purified $\beta$-1,3-glucanase, no evident effect occurred in the mycelium (figures not shown). These findings were in contrast with the results reported for treatment of the $C$. perniciosa with a
$37 \mathrm{kDa}$ chitinase (De Marco et al., 2000), 18.8 $\mathrm{kDa}$ protease (De Marco and Felix, 2002) and a 36 $\mathrm{kDa} \mathrm{N}$-acetylglucosaminidase (De Marco et al., 2004) produced by the same isolate (1051) of $T$. harzianum. Research on the possible mechanisms involved in biological control by Trichoderma species has led to several alternative explanations for successful biocontrol (Howell, 2003). In brief, enzymes such as chitinases and/or glucanases produced by the biocontrol agent are responsible for suppression of the plant pathogen. These enzymes would catalyse the break down of the 
polysaccharides chitin and $\beta$-glucans destroying the cell integrity. It could be also suggested that proteases produced by the mycoparasitic fungus would hydrolysed the enzymes produced by the phytopathogen (Elad and Kapt, 1999). Transformants of $T$. longibrachiatum (CECT2606) over-expressing a gene encoding $\beta-1,4-$ endoglucanase, were slightly more effective in the biocontrol of Pythium ultimum. However, it was also concluded that a mixture of enzymes might be necessary for efficient cell wall lysis (Migheli et al., 1998). The possibility that the $\beta-1,3$-glucanase reported here acted in vivo on the $C$. perniciosa cell wall only in combination with others micolytic enzymes was so far not discarded.

\section{RESUMO}

Uma $\beta$-1,3-glucanase foi produzida por Trichoderma harzianum em cultura contendo quitina como fonte de carbono. Duas proteínas com atividade de $\beta$-1,3-glucanase foram purificadas através de cromatografia de interação hidrofóbica. As massas moleculares destas proteínas foram de $29 \mathrm{kDa}$ e $36 \mathrm{kDa}$. A proteína de $36 \mathrm{kDa}$ foi caracterizada quanto à influência das condições de $\mathrm{pH}$ e temperatura. A atividade máxima foi encontrada em $\mathrm{pH}$ 5,0 e temperatura de $50^{\circ} \mathrm{C}$. A proteína purificada mostrou-se muito sensível à temperatura. Aproximadamente $60 \%$ da atividade original foi perdida por incubação da proteína a $45^{\circ} \mathrm{C}, 50^{\circ} \mathrm{C}$ e $60^{\circ} \mathrm{C}$, por $30 \mathrm{~min}$. $\mathrm{O} \mathrm{K} \mathrm{K}_{\mathrm{M}}$ aparente e a $\mathrm{V}_{\max }$ para hidrólise de laminarina em $\mathrm{pH} 5,0$ à $37^{\circ} \mathrm{C}$, foram de $0,099 \mathrm{mg}$ de açúcar redutor/mL e $0,3 \mathrm{mg}$ de açúcar redutor/min.mL, respectivamente. Esta enzima mostrou-se insensível a compostos orgânicos e íons metálicos, exceto íon férrico o qual em uma concentração de $1 \mathrm{mM}$, inibiu em aproximadamente $100 \%$ a atividade da enzima. Ao contrário de outras enzimas hidrolíticas (quitinase e protease) produzidas pelo mesmo isolado 1051 de $T$. harzianum, a $\beta$-1,3-glucanase descrita aqui não afetou a integridade da parede celular do fitopatógeno Crinipellis perniciosa.

\section{ACKNOWLEDGEMENTS}

JLM acknowledges the post-doctoral research fellowship from Coordenação de Aperfeiçoamento de Pessoal de Nível Superior do Brasil (CAPES/PRODOC).

\section{REFERENCES}

Azevedo, A. M. C.; De Marco, J. L. and Felix, C. R. (2000), Production of hydrolytic enzymes by Trichoderma sp. isolate with antagonistic activity against Crinipellis perniciosa, the causal agent of witches' broom of cocoa. FEMS Microbiol. Lett., 188, 171-175.

Bamforth, C.W. and Quain, D.E. (1990), Enzymes in brewing, and distilling. Aberdeen: University Press.

Bartinicki-Garcia, S. (1973), Fundamental aspects of hyphal morphogenesis. In: Microbiology differentiation. Edited by J.M. Ashnorthand and J.E. Smith. Cambridge. University Press, Cambridge, U.K. pp. 245-268.

Bauer, M.W.; Driskill, L.E., Gallen, W., Snead, M.A., Mathur, E.J. and Kelly, R.M. (1999), An endoglucanase, eglA, from the hyperthermophilic arcahaeon Pyrococcus furiosus hydrolyzes - $\beta-1,4$ bonds in mixed linkage $(1 \rightarrow 3,1 \rightarrow 4)-\beta$-D-glucans and cellulose. J. Bacteriol., 181, 284-290.

Blum, H.; Beier, H. and Gross, H. (1987), Improved silver staining of plant proteins, RNA and DNA in polyacrilamide gels. Electrophoresis, 8, 93-99.

Cherif, M. and Benhamou, N. (1990), Cytochemical aspects of chitin breakdown during the parasitic action of a Trichoderma sp. on Fusarium oxysporium sp. radicis-licopersici. Phytopathology, 80, 14061414.

Chet, I. (1987), Trichoderma - application and mode of action, and potential as biocontrol agent of soilborne plant pathogenic fungi. In Innovative aproaches to plant disease control. Edited by I. Chet. John Wiley, New York. pp.137-160.

Dais, P. and Perlin, A.S. (1982), High-field ${ }^{13}$ C NMR spectroscopy of $\beta$-D-glucans, amylopectin, and glycogen. Carbohydr. Res., 100, 103-116.

De La Cruz, J.; Pintor-Toro, J.A., Benitez, T., Llobel, A. and Romero, L.C. (1995), A novel endo- $\beta-1,3-$ glucanase, BGN 13.1, involved in the mycoparasitism of Trichoderma harzianum. J. Bacteriol., 177, 69376945.

De Marco, J.L.; Lima, L.H., Sousa, M.V. and Felix, C.R. (2000), A Trichoderma harzianum chitinase destroys the cell wall of the phytopathogen Crinipellis perniciosa, the causal agent of witches' broom disease of cocoa. World J. Microbiol. Biotechnol., 16, 383-386.

De Marco, J.L. and Felix, C.R. (2002), Characterization of a protease produced by a Trichoderma harzianum isolate which controls cocoa plant witches' broom disease. BMC Biochemistry; 3:3. Available at: http://www.biomedcentral.com/1472-2091/3/3. 
De Marco, J.L.; Valadares-Inglis, M.C. and Felix, C.R. (2003), Production of hydrolytic enzymes by Trichoderma sp. isolate with antagonistic activity against Crinipellis perniciosa, the causal agent of witches' broom of cocoa. Braz. J. Microbiol., 34, 3338.

De Marco, J.L.; Valadares-Inglis, M.C. and Felix, C.R. (2004), Purification and characterization of and Nacetylglucosaminidase produced by Trichoderma harzianum strain which controls Crinipellis perniciosa. Appl. Microbiol. Biotechnol. 64, 70-75.

Elad, Y. and Kapt, A. (1999), The role of Trichoderma harzianum protease in the biocontrol of Botrytis cinerea. Eur. J. Plant Pathol., 105, 177-189.

Esslinger, M. and Nazriss, L. (1985), Ueber den Einfluss von $\beta$ - und $\alpha$-glucanen auf die Filtrierbrkeit des Bieres. Eur. Brew. Conv. Proc. Cong. 411-418.

Herrera-Estrella, A. and Chet, I. (1998), Biocontrol of bacteria and phytopathogenic fungi. In: Agricultural Biotechnology, Arie, A., Ed., pp. 263-82. Marcel Dekkere, NY.

Howell, C.R. (2003), Mechanism employed by Trichoderma species in the biological control of plant diseases: The history and evolution of current concepts. Plant Dis., 8, 1-10.

Jeroch, H.; Aboud, M., Engerer, K.H. and Grebhsrdt, G. (1988), Evaluation of an enzyme preparation containing $\beta$-glucanase in broiler fattening rations based on barley. Arch. Anim. Nutrit, 38, 399-404.

Laemmli, U.K. (1970), Cleavage of structural proteins during the assembly of the head of bacteriophage $T_{4}$. Nature, London, 227, 680-685.

Lima, L.H.C.; Ulhoa, C.J., Fernandes, A.P. and Felix, C.R. (1997), Purification of a chitinase from Trichoderma sp. and its action on Sclerotium rolfsii and Rhizoctonia solani cell walls. J. Gen. Appl. Microbiol. 43, 31-37.

McCleary, B.V.; Shameer, I. and Glennie-Holmes, M. (1988), Measurement of 1-3,1-4- $\beta$-D-glucan. Methods in Enzymology, 160, 545-551.

Migheli, Q., Gonzalez-Cnadelas, L., Dealessi, L., Camponogara, A. and Ramson-Vidal, D. (1998), Transformants of Trichoderma longibrachium overexpressing the $\beta$-1,4-endoglucanase gene egl1 show enhanced biocontrol of Pythium ultimum on cucumber. Phytopathology, 88, 673-677.
Miller, G.L. (1959), Use of dinitrosalicylic acid reagent for the determination of reducing sugar. Anal. Chem., 31, 426-428.

Murray, P.G.; Grassick, A., Laffey, C.D., Cufffe, M.M., Higgins, T., Savage, A.V., Planas, A. and Guohy, M.G. (2001), Isolation and characterization of a thermostable endo- $\beta$-glucanase active on $1,3-1,4-\beta$ glucans from the aerobic fungus Talaromyces emersonii CBS 814.70. Enzyme Microb. Technol., 29, 90-98.

Noronha, E.F. and Ulhoa, C.J. (1996), Purification and characterization of an endo- $\beta$-1,3-glucanase from Trichoderma harzianum. Can. J. Microbiol., 42, 1039-1044.

Noronha, E,F. and Ulhoa, C.J. (2000), Characterization of a 29-kDa $\beta$-1,3-glucanase from Trichoderma harzianum. FEMS Microbiol. Lett., 183, 119-123.

Peterson, G.L. (1977), A simplification of the protein assay method of Lowry et al. which is more generally applicable. Anal. Biochem., 83, 346-356.

Pitson, S.M.; Seviour, R.J. and Mcdougall, B.M. (1993), Noncellulolytic fungal $\beta$-glucanases: Their physiology and regulation. Enzyme Microb. Technol., 15, 178-192.

Schwimming, S.; Schwartz, W.H. and Staudenbauer, W.L. (1991), Properties of a thermoactive $\beta$-1,3-1,4glucanase (Lichenase) from Clostridium thermocellum expressed in Escherichia coli. Biochem. Biophys. Res. Comm., 177, 447-52.

Totsuka, A. and Usui, T. (1986), Separation and characterization of the endo- $\beta$-1,3-glucanase from Rhizoctonia solani. Agric. Biol. Chem., 50, 543-550.

Received: November 23, 2004; Revised: August 02, 2005; Accepted: September 01, 2006. 
PÁGINA

EM

BRANCO 